\title{
Sculptors' signatures on Iberian stone statues from Ipolca-Obulco (Porcuna, Jaén, Spain)
}

\author{
Teresa Chapa ${ }^{1}$, María Belén ${ }^{2}$, M. Isabel Martínez-Navarrete ${ }^{3}$, \\ Alicia Rodero ${ }^{4}$, Bautista Ceprián ${ }^{5} \&$ Juan Pereira $^{6}$
}

With the help of a modern mason, the authors have discovered a series of scarcely visible markings on well-known limestone statues from southern Spain dating back to the fifth century BC. Unrelated to letters or religious symbols, their best point of comparison seems to lie with the kind of signature used by masons to denote a craftsman or workshop. One can certainly forgive any sculptor an expression of pride in the elegant and complex carvings of the Iberian culture.

Keywords: Iberia, Iberian culture, Iron Age, sculpture, statues, art, artists

\section{Introduction}

Iberian culture is defined as that which flourished from the sixth to the first centuries BC within the Iberian Peninsula. Its roots can be determined from at least the ninth century $\mathrm{BC}$, when the local late Bronze Age population developed a strong interaction with the Phoenicians, who had founded important establishments on the Spanish southern coast. The Phoenician presence provoked economic changes among the indigenous population, investing it with a special personality within the Mediterranean context (Cunliffe \& Keay 1995; Ruiz \& Molinos 1998).

The major features of the Iberian culture include a tendency towards urban structures, an intensification of long-distance trade, specialisation in metallurgical and ceramic production, and the formalisation of a particular cosmology that had no apparent relationship with that of the Greek world. Nonetheless, Iberian religious customs shared with those of Greece or Etruria the practice of erecting stone statues in sanctuaries and cemeteries.

Eastern Andalusia saw an appreciable increase in the number of sculptors' workshops linked to the process of urbanisation, a development with its roots in the Orientalising period (eighth-sixth centuries BC) that would reach its climax in the fifth century BC. Numerous

\footnotetext{
Department of Prehistory, Facultad de Geografia e Historia, Universidad Complutense de Madrid, 28040 Madrid, Spain (Email: tchapa@ghis.ucm.es)

2 University of Seville, 41004 Seville, Spain (Email: mbelend@telefonica.net)

Spanish National Research Council, E-28006 Madrid, Spain (Email: cehmn1g@ih.csic.es)

National Archaeological Museum, C. Serrano 13, Madrid, Spain (Email:alicia.rodero@MCU.es)

5 Cástulo Museum, Calle General Echagüe 2, 23700 Linares, Spain (Email: bautista.ceprian.ext@ juntadeandalucia.es)

6 University of Castilla-La Mancha, Plaza Padilla, 45071 Toledo, Spain (Email: Juan.Pereira@uclm.es)
}

Received: 5 September 2008; Accepted: 27 November 2008; Revised: 5 January 2009

ANTIQUITY 83 (2009): 723-737 


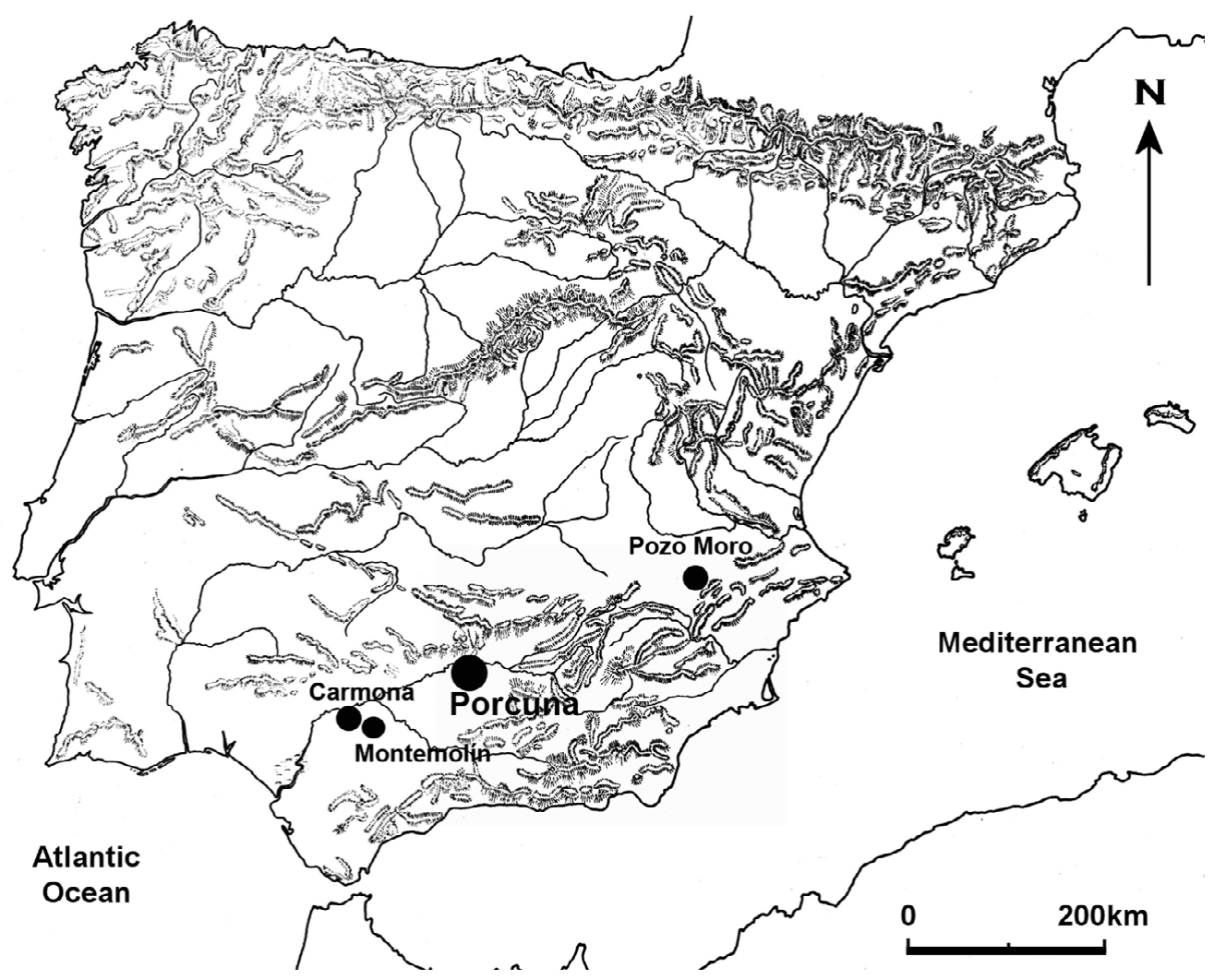

Figure 1. Location of Ipolca-Obulco (Porcuna, Jaén, Spain) and other sites cited on the text.

pieces of sculpture have been discovered in the province of Jaén, some with works of great quality, such as the Pajarillo de Huelma (Chapa et al. 2006). However, the most important site in terms of the number and quality of pieces is that of Cerrillo Blanco de Porcuna, known as Ipolca to the Iberians and as Obulco in Roman times (Figure 1). The sculptures were cut in limestone and unfortunately they were recovered with no archaeological control. Most of them were discovered in a ditch dug at the edge of an Orientalising cemetery (Blázquez \& González Navarrete 1985; González Navarrete 1987), although the sculptures can be dated by means of their style during the fifth century BC. A total of 1486 fragments of different sizes were recovered that were later partially pieced together at the Jaén Museum, where they are still held. The most complete study of these fragments was made by Negueruela (1990), although other interesting works have been published (León 1998; Olmos 2002).

All the studied Ipolca sculptures were violently broken and dumped in the abovementioned ditch, although some fragments appear to have been scattered over the surface of the surrounding hillside - some were even used as construction material in fourth-century graves. The destruction of these pieces has been related to the rejection of the elite groups that were represented, but it could also have been the result of a ritual transfer from the sanctuary to which they belonged, at the moment this monument was abandoned, renewed or moved to a new place (Zofío \& Chapa 2005). 
To date, research has been focused on iconography and style, stressing the links between Iberian and eastern Greek, especially Ionic workshops. However, those authors who have compared them indicate the lack of direct dependency between these two areas. Iberian sculpture has its own tastes and formulae, and in general does not coincide properly with supposedly Hellenic models in terms of its subjects nor technical features (Boardman 1994: 69; Marcadé 1997; Croissant 1998). Moreover, the recent discovery of a stone sculpture showing clear Phoenician influence in the Tartessian village of Carmona (Belén \& García Morillo 2006) indicates this type of sculpture was already present in pre-Iberian times. Therefore, the origins of Iberian stone sculpture must be searched on the Orientalising period, with strong links with Phoenician religion and iconography. Similarities with Greek art along the development of Iberian sculptures can be considered as the introduction of new techniques and styles without changing the basic foundations of the local production.

Our purpose is to analyse the manufacture of these Iberian sculptures, from the selection of the stone to the finished piece. The aim is to determine the decisions taken in their design, the systems of stone extraction and transport employed, the tools and the cutting methods used, the places where the finished pieces were located at monuments, and the possible processes behind their deterioration or destruction. Unlike Greek and Roman sculpture, both of which have been well-studied from these viewpoints (Jockey 1998; Palagia 2006), the technique of Iberian sculpture has been the subject of only a few basic studies (Negueruela 1990-1991; Blánquez \& Roldán 1994).

During the detailed examination of the Ipolca sculptures undertaken by our team, engraved marks were noted on the surface of some pieces. We propose that these might be interpreted as sculptor or workshop marks. Until now, only one of the pieces from Ipolca was known to have a possible inscription that was interpreted as a name (Untermann 1990: 658-9). The signs studied here are non-epigraphic marks, and it is the first time they are being recorded on any Iberian sculpture.

\section{The sculptures and their marks}

The study of these sculptures has allowed different groups to be distinguished (Blanco 1987, 1988 a $\&$ b). One of these corresponds to some well-armed warriors killing others who are inadequately prepared for battle. Unfortunately, the head of only one of the figures has been conserved. On different occasions the piece has been described to share features with Ionic art (Rolley 1994: 407), although no exact parallels can be traced (Figure 2). A second group is composed of masculine and feminine figures that appear to be at a sanctuary. One of the women is carrying a snake on her left shoulder, and the other is holding two rams close to his body. The fracture of the sculptures makes it very difficult to determine what these people are doing, although their activities appear solemn, in accordance with a religious context (Figure 3). A large number of representations of real and fantastic animals, including griffins, birds, dogs, wolves, lambs and bulls, have also been recovered. These appear to be static figures or to belong to scenes depicting hunting or acts of aggression. They are of great interest since they are the finest of the Ipolca sculptures. The signature marks discussed in the present work were made on these figures. 



Figure 2. Two sculptures from the group of warriors.
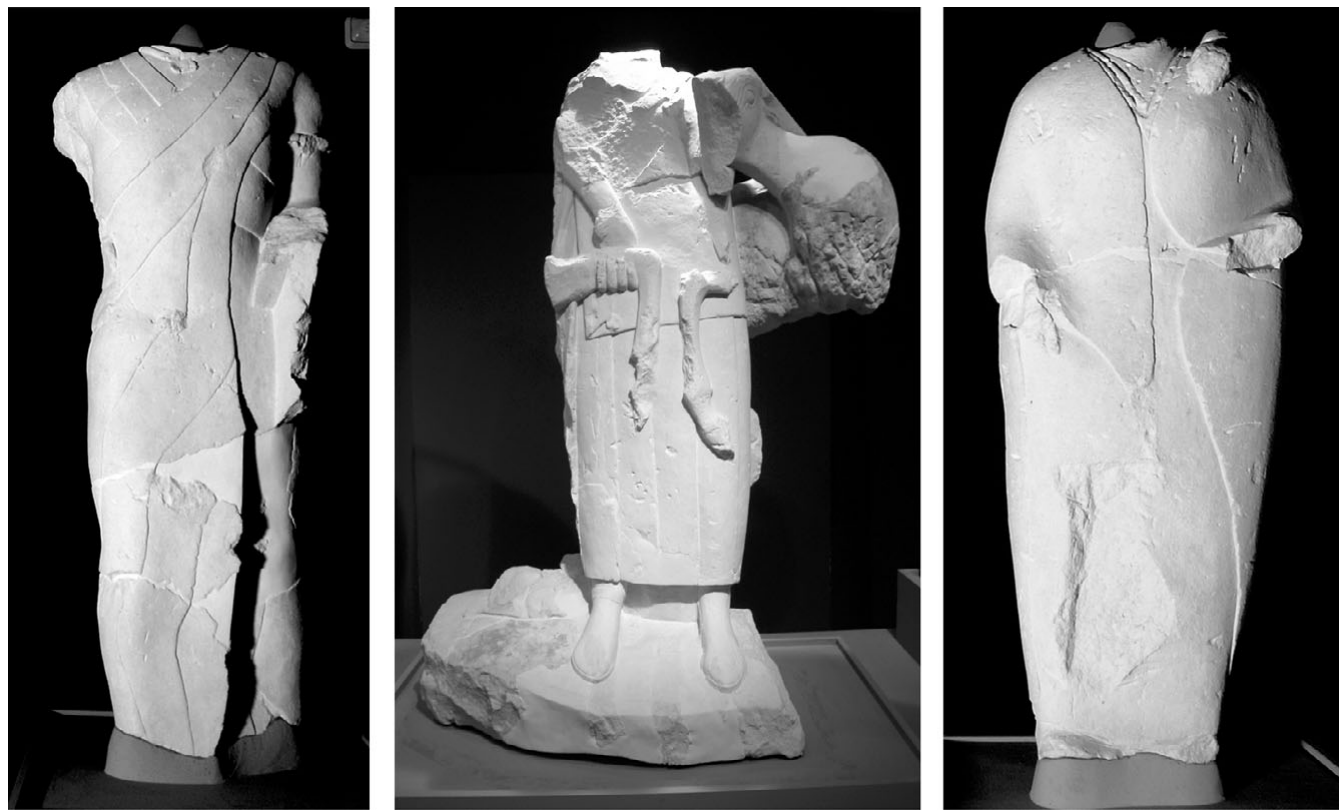

Figure 3. Sculpture group known as the 'priests and priestesses'.

The marks found to date appear only on certain pieces representing animals, although since many of the sculptures are incomplete it cannot be ruled out that they were also made on other types of figure. The marks were engraved with a very fine-pointed instrument and are hardly visible without special lighting. Although these works have been held at the Jaén Museum for over 25 years, the mentioned marks have hitherto gone undetected by researchers. They were first noticed by Francisco Aguilera, an experienced quarryman 



Figure 4. Lion-griffin being attacked by a snake.

and sculptor from Porcuna who accompanied us to the museum to assess the techniques employed in the production of the sculptures. On inspection, Mr Aguilera immediately noticed the marks, and based on his own experience, suggested them to be signature marks. There follows a description of the pieces carrying the marks and the marks themselves.

1. Lion-griffin with palmette and snake (height $0.779 \mathrm{~m}$, length $0.56 \mathrm{~m}$, width $0.26 \mathrm{~m}$ ) (Figure 4). This sculpture represents an animal that would clearly be a lion were it not for a crest running down the back of its neck - the mark of a griffin. The beast lacks wings and has teeth rather than the beak of a bird of prey typical of griffins, tending to confirm its feline identity. Anyway, the sculptor emphasised ambiguity as a main feature of this monster. The animal rests its claws on a half palmette and is in the process of violently turning its head to confront a snake that has wrapped itself around its body. The head of the snake has not been preserved, but a series of marks repeated in pairs on the body and face of the lion-griffin would appear to represent where the snake has sunk its teeth. The entire piece, which was cut from a single block of limestone, is extraordinarily expressive and shows an understanding of volume, a quality that would surely be reinforced if the hindquarters of the animal had been conserved. The surface of the stone was carefully polished, but at the points of most difficult access for the sculptor - and therefore those least visible to the observer - chisel marks are still visible. 

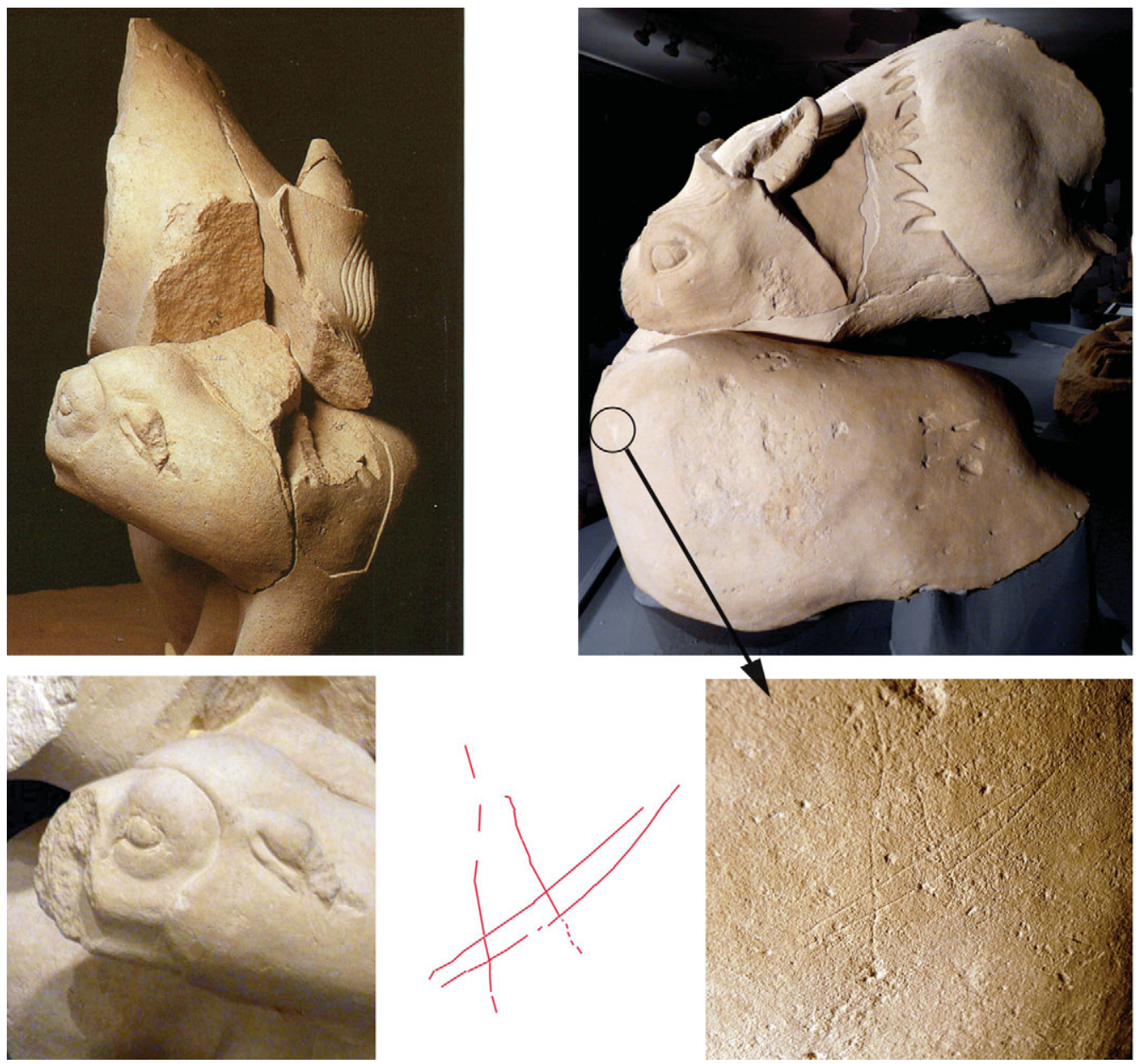

Figure 5. Wolf attacking a lamb.

The engraved sculptors' marks are found on the back of the lion-griffin's neck, and are formed by interconnecting lines at angles to one another. The maximum width of the mark is $75 \mathrm{~mm}$ and its maximum height $80 \mathrm{~mm}$. The impacts sustained during the destruction of the piece caused the deterioration of the surface, and some of the lines making up these signatures are truncated at certain points.

2. Wolf attacking a lamb (height $0.77 \mathrm{~m}$, length $0.55 \mathrm{~m}$, width $0.39 \mathrm{~m}$ ) (Figure 5). This piece remains incomplete, despite a good part of it having been reconstructed from various fragments found at the site, and represents a lamb being bowled over by a charging wolf. The wolf, with its jagged mane about its neck, has sunk its fangs into the upper part of the lamb's back and has dragged them backwards, leaving marks in the lamb's flesh and pulling back the victim's skin. The wolf's pupils express the tension of the situation, while its frown lines indicate the violence of the attack. Again, expressivity is the main argument of the sculpture, the sculptor clearly having undertaken a careful study of a complex position and attitude. 



Figure 6. Hunter with dog.

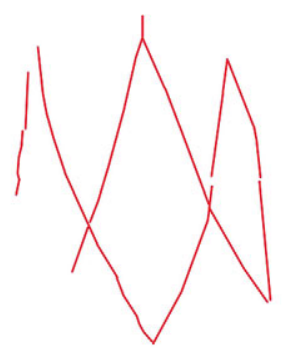

The engraved mark is found on the lamb's left side, next to the area where the wolf's bite has lifted the skin. Its shape reminds one of the letter 'A'. Lying a little obliquely, its vertical lines, with a maximum height of $50 \mathrm{~mm}$, are somewhat discontinuous. In contrast, its horizontal lines, with a maximum length of $55 \mathrm{~mm}$, are more continuous. One of the impacts suffered by the piece in the process of its destruction affected the lower horizontal line, truncating it. Once again, the mark is very fine and almost invisible without adequate illumination.

3. Hunter with hare and dog (height $0.80 \mathrm{~m}$, width $0.60 \mathrm{~m}$ ) (Figure 6). The lower part of this piece was produced in relief, while the upper part of the human figure is independent of any background. This work has been reconstructed from eight fragments recovered at the site, but the hunter's head is still missing, along with his right foot, and a large part of the dog's head and legs. The energy of the scene is revealed by what remains of the dog's open mouth, which shows a panting tongue. Both the backplate (thickness $0.14 \mathrm{~m}$ ) and the base (maximum height $0.16 \mathrm{~m}$ ) of the work show clear chisel marks about $20 \mathrm{~mm}$ in width. There appears to have been no attempt to hide them, suggesting the lower part of the figure might have been placed in the ground while the sides made contact with similar structures to produce something like a frieze.

The engraved sculptors' mark (maximum height $80 \mathrm{~mm}$, width $55 \mathrm{~mm}$ ) lies on the dog's right shoulder blade. Despite its fine tracing it is the most easily observed of all 


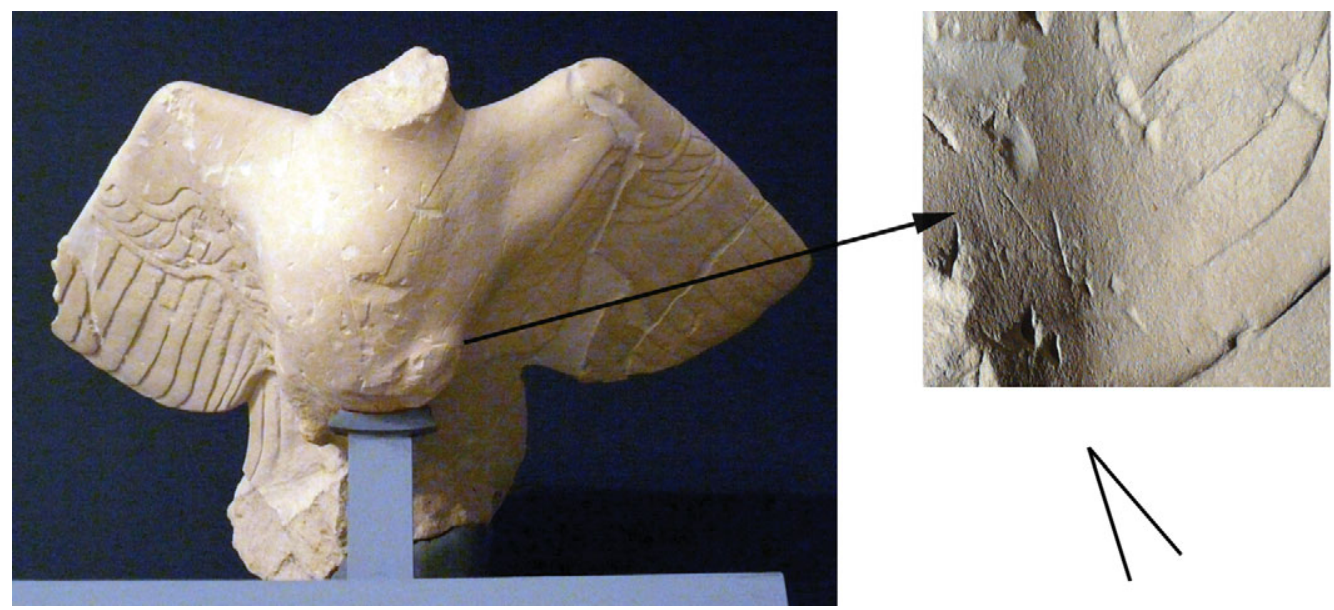

Figure 7. Bird or harpy.

those inspected. In fact, its presence was mentioned in an internal report regarding the consolidation and restoration of these sculptures, although this was never mentioned in any later archaeological studies. The mark consists of interlocking lines forming three rhomboids of unequal size, the one on the right-hand side being the smallest and the one on the left remaining incomplete. A small vertical line $10 \mathrm{~mm}$ in length extends upwards from the tip of the central rhombus.

4. Body of a bird with outstretched wings (maximum height $0.70 \mathrm{~m}$, maximum width $0.98 \mathrm{~m}$ ) (Figure 7). The back of this piece has been left unfinished, indicating that it was to be viewed from below. The piece has been reconstructed from five fragments, but the head and feet are missing. The two large wings are outstretched, each showing two clear sets of feathers separated by engraved bands. The bird's body is large, leading to interpretations of it representing an eagle, but the possibility that it is intended as a harpy cannot be rejected.

The surface shows signs of erosion, with many impacts and scratches. However, a potential signature mark can be seen on the left side of the body near the insertion of the wing: two straight incisions that meet to form a ' $V$ ' shape which appears to have the same characteristics as those described above. In the area where the lines meet the piece has suffered much surface damage, which makes it impossible to determine whether these lines extended any further.

5. Hock of a horse with human face and inscription (height $0.17 \mathrm{~m}$, width $90 \mathrm{~mm}$, thickness $115 \mathrm{~mm}$ ) (Figure 8). The surface of the piece was smoothed down to allow the facial features to stand out, which consist of some roughly hewn eyes and mouth, and a nose flattened horizontally at the level of the nostrils. This figure, made after the horse's leg itself was completed, shows an inscription in a vertically-arranged frame divided into two unequal parts. The finely engraved signs within were studied by Untermann (1990: 658-9), who identified them as belonging to the Southern Iberian alphabet, and to possibly reflect a person's name, perhaps that of the sculptor. However, the preservation of these lines is very poor as they have suffered at the hands of erosion, and their reading and meaning are very doubtful (de Hoz 1995: 168). 



Figure 8. Hock of a horse with human face and inscription.

\section{Interpreting the marks on the Ipolca sculptures}

As it has been previously stated, this is the first time such signs have been noticed on the surface of Iberian sculptures, and they need to be interpreted carefully within the cultural and material contexts to which they belong. The marks are clearly different to the signatures recorded in other Mediterranean sculptural productions. During the same period, Greek sculptors sometimes signed their work, a mark of personal prestige transferable to the client (Viviers 1992; Duplouy 2006). Potters, painters, goldsmiths and jewellery-makers could also sign their products, both in Greece and pre-Roman Italy (Marcadé 1957; Colonna 1975). A small number of imported signed objects arrived in the Iberian Peninsula, such as the sixth-century BC fragmented kylix attributed to Eucherios, found at a tomb in the Orientalising site of Medellín (Olmos 2000: 261). Further, although it is commonly said that the theocratic, political and social structure of the Middle East did not favour the recognition of individual artists (Siebert 1978: 113; Stewart 1990: 67), a review of the materials available from that area has revealed the signatures of sculptors (Laroche 1958), always within a clearly epigraphic context.

However, the marks engraved on the studied Iberian pieces do not correspond well to the letters used in the different forms of Iberian writing (Figure 9A). In the south and east of the Iberian Peninsula there were two forms of writing during the Iberian period (de Hoz 1997: 210): 'Levantine Iberian' and 'Southern Iberian'. Both are semi-syllabic, i.e. they have signs that represent syllables plus others that represent individual phonemes. An 


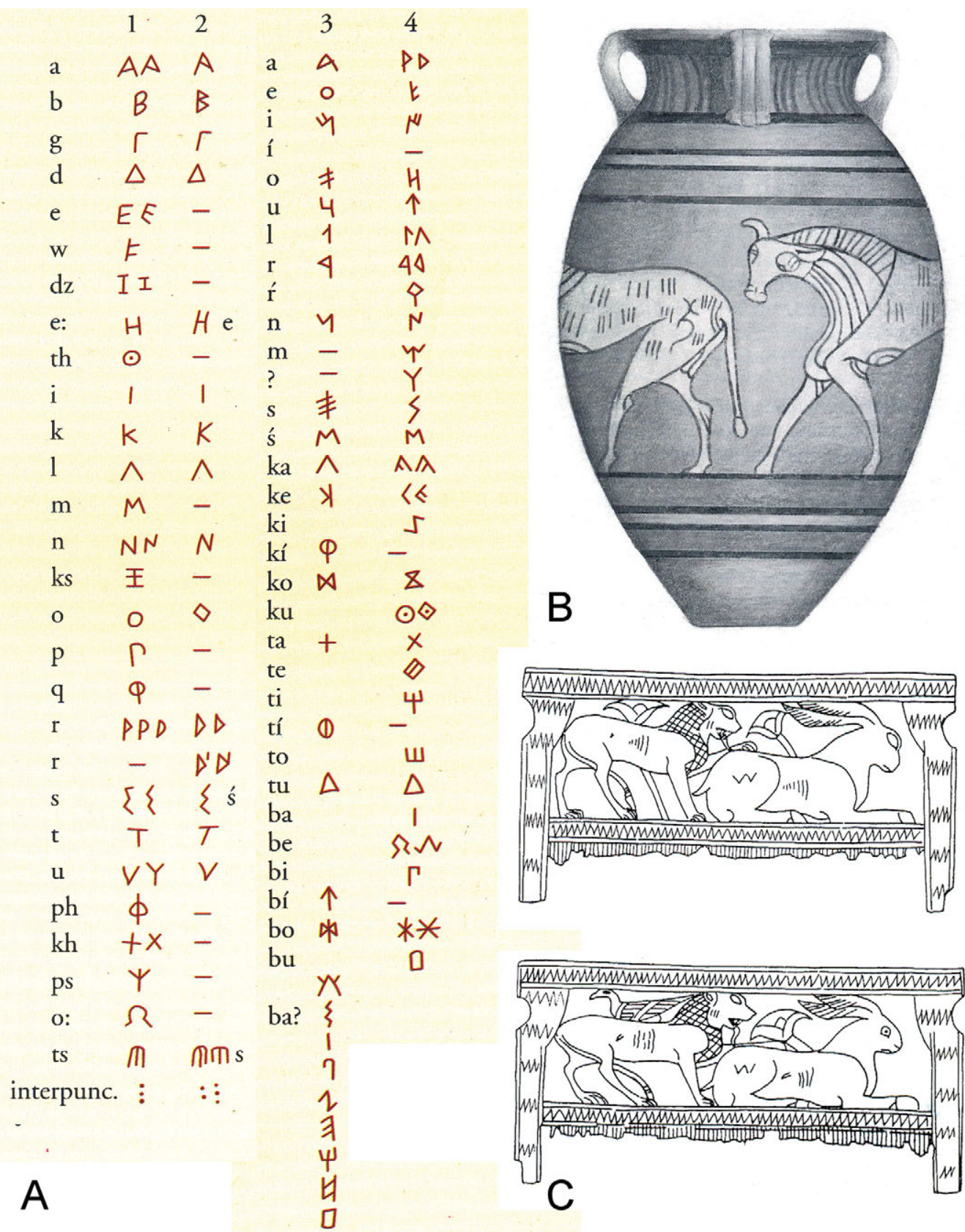

Figure 9. A) Iberian writing signs: 1) proposed Phoenician model; 2) South-western writing/Southern; 3) Iberian; 4) Eastern or 'Levantine' Iberian (modified from de Hoz 1997); B) painted pottery of the Tartessian sanctuary at Montemolin (Seville) (de la Bandera 2002); C) ivory combs from Cruz del Negro (Carmona) (Moret \& Rouillard 1997).

area of the south-east was also home to a Greek-Iberian alphabet that used the Ionic Greek alphabet for writing in Iberian (de Hoz 1995). However, the present signs do not match any known letters in these alphabets. The majority of preserved Iberian inscriptions have 
been found on lead supports and are usually linked to commercial transactions or funerary contexts - into which the present marks clearly do not fall - while those on ceramic and other supports are generally later than the Second Punic War and thus not contemporaneous with the stone sculptures studied. Indeed, it seems that the usual development of Iberian societies made only an exceptional use of writing before the third century BC. As the marks engraved on the sculptures do not match with any Iberian letter, we tend to think that they are more likely to represent lapidary signs related to particular individuals or workshops.

Certainly, the iconography of the previous Orientalising period also made use of signs, but in a different way. A number of signs can be seen on the bodies of the bulls and lions drawn on the sides of ceramic vases from the Tartessian Montemolín sanctuary (de la Bandera 2002: 152, Lam. II), or on the ivory combs of the Bonsor Collection (Moret \& Rouillard 1997: 5) (Figure 9B-C). These objects have strong links with the eastern Mediterranean, especially the Phoenician world (Kantor 1947; Buchholz 2005: 95-8), where these kinds of marks appear on similar supports as well as on tridracnae (Stucky 2007: 221, Cat. 330). However, their typology and position favour their interpretation as decorative motifs, stylised representations of the anatomy, symbolic indicators, or even assembly instructions (Millard 2005). In no case do they appear to be signature marks.

The oldest stone Iberian sculpture, dated in the sixth century BC, has unmistakeable roots in the Orientalising Tartessian period and shows some parallels with the previously cited examples. Some stone bulls from the Spanish Mediterranean area wear an engraved rectangle on the forehead that resembles an ox-hide ingot, a motif that was widespread at Tartessos and in the initial phases of Iberian culture (Chapa 2005). At Ipolca, the sculpture of a bull showing clear Orientalising iconography was recovered years before the finding of the Cerrillo Blanco. The piece shows floral motifs on the shoulders and forehead, as well as deep lines on its hindquarters (Blanco 1960: 37-40, Figures 56-7). These motifs are carefully designed and profoundly engraved on the bull's body, and therefore are an important part of the figure. Ingots and floral motifs are frequently used in Orientalising iconography, and they should be interpreted as symbolic features linking this animal to its associated deities and rituals. These marks, therefore, do not coincide with those of the studied Ipolca sculptures, which must be interpreted in other terms (Figure 10).

Certain later Iberian objects are known to carry identifying marks, such as ceramic recipients (Mata \& Soria 1997), weaving looms and brooches (Flores et al. 1999). Generally, these are interpreted as signs of property, origin or content, although no pattern has been demonstrated that can confirm any of these possibilities. However, the few texts that have appeared on ceramic vases or metallic objects are much younger (the end of the third century BC at the latest) than the studied Ipolca sculptures. The word 'ekiar' appears frequently on these supports, and has sometimes been interpreted to mean 'made by', but it could also mean 'property of' (de Hoz 1992: 335). The actual meaning remains elusive given the difficulties that the reading and translation of Iberian languages still entail.

In summary, none of these examples provide an adequate explanation for the marks that have been noticed on the surface of the sculptures. Closer to our object of study are the marks made by the quarrymen and stonemasons on some Iberian stone monuments. The Pozo Moro (500 BC) tower in Albacete, which rises above four lions at its corners, shows 

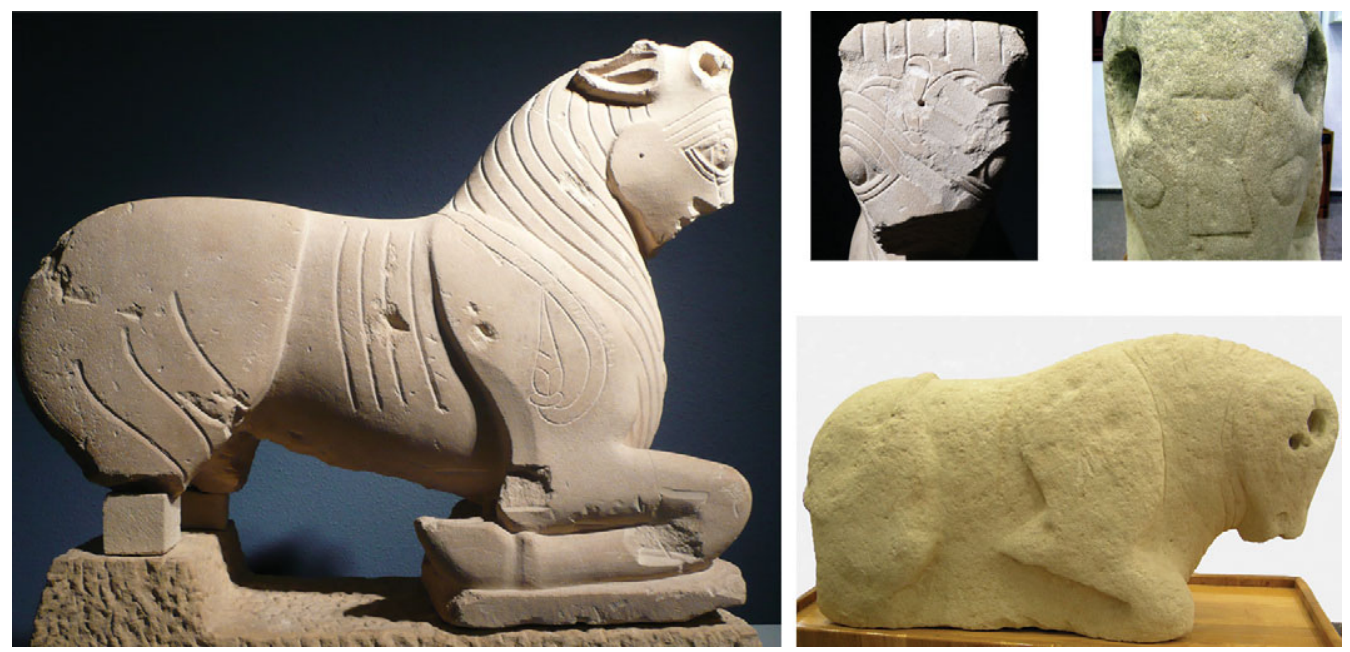

Figure 10. Orientalising stone bulls: 1) Porcuna, with floral motifs engraved on the body and forehead; 2) Monforte del Cid, with an 'ox-hide' ingot sign on the forehead.

marks on some of its ashlars. Even though they were only finely engraved, they are perfectly visible from a certain distance (Figure 11), and were probably intended to indicate the exact position of the blocks (Almagro-Gorbea 1983: Lam. 31).

We could then turn to the world of specialised stoneworkers in order to find an adequate context for these expressions. In medieval times, quarrymen, stonemasons, sculptors and donors often 'signed' their work for personal recognition or the identification of their workshop, generally for economic reasons. However, engravings were also made for practical purposes, such as transport information, or to denote the position of a piece in a monument (Esquieu \& Hartmann-Virnich 2007).

The most outstanding features of the Ipolca marks are their non-epigraphic character and the fineness of their traces, which would not have left them noticeable to a cursory look. These facts show that their main goal was to leave a very personal signature only detectable by their author and maybe other specialists that were familiar with the sculptural process. We cannot discard also economic reasons, as the marks identify authorship, and thus justify payment, but very often traditional stonemasons and sculptors engrave hidden marks on their works just as a sign of self- and peer-recognition.

Ancient sculptures that carry the signatures of their makers are naturally in the minority, even in the Greek world. Certainly, the ideological and social contexts of Iberian groups seem to have considered the social status of sculptors better as manual workers than artists. As far as we know, neither their signature, nor that of the client, was considered appropriate to appear on the surface of the sculpture. The scarce use of a formal script among the population reinforced this tendency. Nevertheless, the makers of these magnificent sculptures probably wanted to leave their mark on their work.

The question remains as to whether this situation reigned in other pre-Roman Mediterranean contexts. Certainly up to now, recognisable authors' signatures to which attention has been paid have always been clearly visible. However, it is possible that other 


\section{Teresa Chapa et al.}
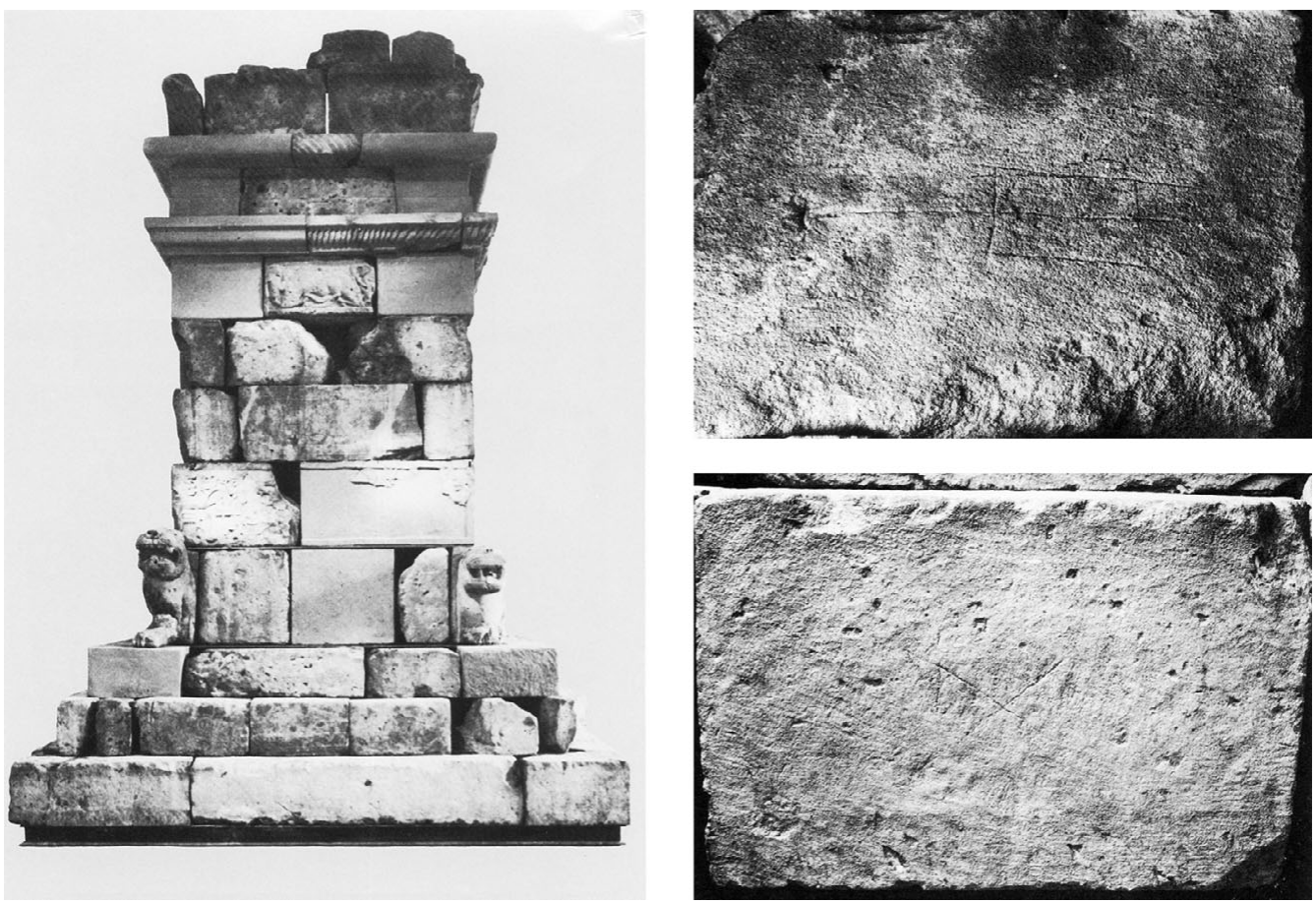

Figure 11. Funerary tower from Pozo Moro (Albacete) and ashlars with position marks (modified from Almagro-Gorbea 1983).

formulae were used to identify sculptors' works. Perhaps many other sculptures from the pre-Roman Mediterranean carry similar marks awaiting discovery.

\section{Acknowledgements}

This paper has been developed within the Research Project HUM2007-60074, funded by the Spanish Ministry of Science and Innovation. We are deeply grateful to the Director of the Jaén Museum, Francisca Hornos and Margarita Sánchez, Keeper of the Jaén Museum, for helping us in different ways while we studied the sculptures. We also want to acknowledge Professor Javier de Hoz for his thorough advice about the engraved signs and their relation with the Iberian language, and to Professors Robert Chapman and Gonzalo Ruiz Zapatero for their helpful and encouraging comments. Finally, the authors feel deeply indebted to Francisco Aguilera, stonemason and sculptor from Porcuna, whose experience and sagacity led to the discovery of a new aspect of the Iberian sculpture.

\section{References}

Almagro-Gorbea, M. 1983. Pozo Moro. El monumento orientalizante, su contexto socio-cultural y sus paralelos en la arquitectura funeraria ibérica. Madrider Mitteilungen 24: 177-392.

Belén, M. \& M.C. Garcła Morillo. 2006. Das Tartessische Carmona. Eine Stadt mit Statuen. Zu dem Neufund einer Statuette. Madrider Mitteilungen 47: 43-58.
Blanco, A. 1960. Orientalia II. Archivo Español de Arqueología 33: 3-33.

- 1987. Las esculturas de Porcuna. I. Estatuas de guerreros. Boletín de la Real Academia de la Historia 184: 405-45.

- 1988a. Las esculturas de Porcuna. II. Hierofantes y cazadores. Boletín de la Real Academia de la Historia 185: 1-27.

- 1988b. Las esculturas de Porcuna. III. Animalia. Boletín de la Real Academia de la Historia 185: 206-34. 


\section{Sculptors' signatures on Iberian stone statues from Ipolca-Obulco (Porcuna, Jaén, Spain)}

Blázquez, J.M. \& J. GonZÁlez NaVArRete. 1985. The Phokaian sculpture of Obulco in Southern Spain. American Journal of Archaeology 89: 61-9.

BLÁNQUEZ PÉreZ, J. \& L. RoldÁn GÓMEZ. 1994. Nuevas consideraciones en torno a la historiografía y tecnología de la escultura ibérica en piedra $\left(1^{a}\right.$ parte). Revista de Estudios Ibéricos 1: 61-84.

BOARDMAN, J. 1994. The diffusion of Classical art in antiquity. London: Thames \& Hudson.

BuchHOlz, H.-G. 2005. Beobachtungen zur nahöstlichen, zyprischen und frühgriechischen Löwenikonographie: Ugarit - Forschungen. Internationales Jahrbuch für die Altertumskunde Syrien-Palästinas 37: 27-215.

CHAPA, T. 2005. Las primeras manifestaciones escultóricas ibéricas en el oriente peninsular. Archivo Español de Arqueología 78: 23-47.

Chapa, T., M. Molinos, A. Ruiz, J. Pereira \& V. MAYORAL. 2006. The Iron Age Iberian sanctuary of 'El Pajarillo' (Huelma, Jaén) and its sculptural narrative. Studia Celtica 40: 1-22.

Colonna, G. 1975. Firme archaiche di artefici nell'Italia Centrale. Mitteilungen des Deutschen Archäologischen Instituts. Römische Abteilung 82(2): 181-92 (Tf. 51-4).

Croissant, F. 1998. Note sur le style des sculptures de Porcuna, in Actas del Congreso Internacional: Los Iberos, Principes de Occidente. Estructuras de poder en la sociedad ibérica: 283-6. Barcelona: Fundación La Caixa.

Cunliffe, B. \& S. Keay. 1995. Social complexity and the development of towns in Iberia: from the Copper Age to the second century $A D$ (Proceedings of the British Academy 86). Oxford: Oxford University Press.

DE Hoz, J. 1992. Estudio epigráfico, in Estudios de Arqueología Ibérica y Romana. Homenaje a Enrique Pla Ballester (Serie de trabajos varios 89-90): 330-44. Valencia: Servicio de Investigación Prehistórica, Diputación Provincial de Valencia.

- 1995. Ensayo sobre la epigrafía griega de la Península Ibérica. Veleia 12: 151-79.

- 1997. Die Iberische Schrift, in Die Iberer: 207-19. Bonn: Kunst-und Ausstellungshalle des Bundesrepublik Deutschland.

De La Bandera Romero, M.L. 2002. Rituales de origen oriental entre las comunidades tartesias, in E. Ferrer Albelda (ed.) Ex Oriente Lux: las religiones orientales antiguas en la Península Ibérica (SPAL Monografías 2): 141-58. Sevilla: Fundación El Monte.

Duplouy, A. 2006. Le prestige des élites. Recherches sur les modes de reconnaisance sociale en Grèce entre les $X$ et $V$ siècles avant J.-C. Paris: Les Belles Lettres.
Esquieu, Y. \& A. Hartmann-Virnich. 2007. Les signes lapidaires dans la construction médiévale: études de cas et probèmes de méthode. Bulletin Monumental 165(4): 331-58, 413-4.

Flores, R., A. Jimeno, F. Morales \& L.M. Gómez. 1999. Marcas y fíbulas anulares de Numancia, in F. Burillo Mozota (ed.) IV Simposio sobre los Celtíberos. Economía. Homenaje a José Luis Argente Oliver: 387-94. Zaragoza: Institución 'Fernando el Católico' (CSIC).

GonzÁlez Navarrete, J. 1987. Escultura Ibérica de Cerrillo Blanco, Porcuna, Jaén. Jaén: Instituto de Cultura.

JOCKEY, P. 1998. La sculpture en pierre dans l'Antiquité: de l'outillage au processus, in M.C. Amouretti \& G. Comet (ed.) Artisanat et matériaux. La place des materiaux dans l'Histoire des Techniques 4: 153-78. Aix-en-Provence: Publications de l'Université de Provence.

KANTOR, H. 1947. The shoulder ornament in Near Eastern lions. Journal of Near Eastern Studies 6(4): 250-64.

LAROCHE, E. 1958. Étude sur les hiérogliphes hittites. Syria 35: 252-83.

LeÓn, P. 1998. La sculpture des Ibères. Paris: l'Harmattan.

MARCADÉ, J. 1957. Recueil des signatures des sculpteurs grecs. Paris: Boccard.

- 1997. Art grec et art ibérique. Dossiers d'Archéologie 228(97): 22-7.

Mata Parreño, C. \& L. Soria Combadiera. 1997. Marcas y epígrafes sobre contenedores de época ibérica. Archivo de Prehistoria Levantina 22: 297-374.

Millard, A. 2005. Maker's marks, owner's names and individual identity, in C.E. Suter \& Ch. Uehlinger (ed.) Crafts and images in contact. Studies on Eastern Mediterranean art of the first millenium BCE: 1-10. Göttingen: Vandenhoeck \& Ruprecht \& Fribourg: Academic Press.

Moret, P. \& P. Rouillard. 1997. Les Ibères. Dossiers d'Archéologie 228: 4-13

Negueruela, I. 1990. Los monumentos escultóricos ibéricos del Cerrillo Blanco de Porcuna (Jaén). Madrid: Ministerio de Cultura.

- 1990-1991. Aspectos de la técnica escultórica ibérica en el siglo V a.C. Lucentum 9-10: 77-83.

Olmos, R. 2000. Copa ática con un busto de Zeus, in P. Cabrera Bonet \& C. Sánchez (ed.) Los Griegos en España. Tras las huellas de Heracles: 261. Madrid: Ministerio de Educación y Cultura.

- 2002. Los grupos escultóricos del Cerrillo Blanco de Porcuna (Jaén). Un ensayo de lectura iconográfica convergente. Archivo Español de Arqueología 75: 107-22. 
Teresa Chapa et al.

Palagia, O. 2006. Greek sculpture. Function, materials and techniques in the Archaic and Classical periods. Cambridge: Cambidge University Press.

Rolley, C. 1994. La Sculpture Grecque. 1. Des origines au milieu du V siècle. Paris: Picard Ed.

Ruiz, A. \& M. Molinos. 1998. The archaeology of the Iberians. Cambridge: Cambridge University Press.

Siebert, G. 1978. Signatures d'artistes, d'artisans et de fabricants dans l'Antiquité classique. Ktema 3: 111-31.

STEWART, A. 1990. Greek sculpture: an exploration. New Haven (CT) \& London: Yale University Press.

STUCKY, R.A. 2007. Les tridacnes à décor gravé, in E. Fontan (ed.) La Méditerranéen des Phéniciens. De Tyr à Carthague (Catalogue de l'Exposition de l'Institut du Monde Arabe, Paris, Novembre 2007 Avril 2008): 219-23. Paris: A. Somogy Eds.
UnTERMANN, J. 1990. Monumenta Linguarum Hispanicarum III: die iberischen inschriften aus Spanien. Wiesbaden: Reichert.

VIVIERS, D. 1992. Recherches sur les ateliers de sculpteurs et la Cité d'Athènes à l'époque archaïque: Endoios, Philergos, Aristoklès. Brussels: Académie Royale de Belgique.

Zofío, S. \& T. CHAPA. 2005. Enterrar el pasado: la destrucción del conjunto escultórico del Cerrillo Blanco de Porcuna (Jaén). Verdolay 9: 95-120. 